\title{
Tumor-associated tissue eosinophilia predicts favorable clinical outcome in solid tumors: a meta-analysis
}

\author{
Guoming $\mathrm{Hu}^{1{ }^{*+}}$, Shimin Wang ${ }^{2+}$, Kefang Zhong ${ }^{1}$, Feng $\mathrm{Xu}^{1}$, Liming Huang ${ }^{1}$, Wei Chen ${ }^{1 *}$ and Pu Cheng ${ }^{3 *}$
}

\begin{abstract}
Background: Activated eosinophils have been deemed to affect carcinogenesis and tumor progression via various mechanisms in tumor microenvironment. However, the prognostic role of tumor-associated tissue eosinophilia (TATE) in human cancers remains controversial. Therefore, we conducted this meta-analysis to better comprehend the association between TATE and clinical outcomes of patients.

Methods: We searched PubMed, Embase and EBSCO to determine the researches assessing the association between TATE and overall survival (OS) and/or disease-free survival (DFS) in patients with cancer, then combined relevant data into hazard ratios (HRs) or odds ratio (OR) for OS, DFS and clinicopathological features including lymph node metastasis etc. with STATA 12.0.

Results: Twenty six researches with 6384 patients were included in this meta-analysis. We found that the presence of TATE was significantly associated with improved OS, but not with DFS in all types of cancers. In stratified analyses based on cancer types, pooled results manifested that the infiltration of eosinophils was remarkably associated with better OS in esophageal carcinoma and colorectal cancer. In addition, TATE significantly inversely correlated with lymph node metastasis, tumor stage and lymphatic invasion of cancer.

Conclusion: TATE promotes survival in cancer patients, suggesting that it is a valuable prognostic biomarker and clinical application of biological response modifiers or agonists promoting TATE may be the novel therapeutic strategy for patients.
\end{abstract}

Keywords: Tumor-associated tissue eosinophilia, Favorable outcome, Human solid tumor, Meta-analysis

\section{Background}

Tumor microenvironment (TME) linked closely with the initiation, promotion, and progression of cancer [1]. Innate and adaptive immunocytes such as mast cells, macrophages and memory $\mathrm{T}$ lymphocytes etc.

\footnotetext{
*Correspondence: hgmplj@126.com; cwzjsx5018@163.com; drchengpu@zju.edu.cn

${ }^{+}$Guoming Hu and Shimin Wang contributed equally to this work. ${ }^{1}$ Department of General Surgery (Breast and Thyroid Surgery), Shaoxing People's Hospital (Shaoxing Hospital, Zhejiang University School of Medicine), Zhejiang 312000, China

${ }^{3}$ Department of Gynecology, Second Affiliated Hospital, Zhejiang University School of Medicine, Zhejiang University, Hangzhou 310009, China Full list of author information is available at the end of the article
}

are the vital components of TME [2]. Multitudinous studies have demonstrated that these immune cells were significantly associated with survival in solid tumors [3, 4]. However, it is essential to distinguish among different types of immune cells as they may play differential roles in the TME. Eosinophils, as the important component of innate immune cells, have proven to play significant roles in a multitude of solid tumors.

Eosinophils are granulocytic leukocytes that are associated with multitudinous pathologic conditions including allergic reactions, parasitic and bacterial

(c) The Author(s). 2020 Open Access This article is licensed under a Creative Commons Attribution 4.0 International License, which permits use, sharing, adaptation, distribution and reproduction in any medium or format, as long as you give appropriate credit to the original author(s) and the source, provide a link to the Creative Commons licence, and indicate if changes were made. The images or other third party material in this article are included in the article's Creative Commons licence, unless indicated otherwise in a credit line to the material. If material is not included in the article's Creative Commons licence and your intended use is not permitted by statutory regulation or exceeds the permitted use, you will need to obtain permission directly from the copyright holder. To view a copy of this licence, visit http://creativecommons.org/licenses/by/4.0/ The Creative Commons Public Domain Dedication waiver (http://creativecommons.org/publicdomain/zero/1.0/) applies to the data made available in this article, unless otherwise stated in a credit line to the data. 
Table 1 Main characteristics of the included studies

\begin{tabular}{|c|c|c|c|c|c|c|c|c|c|c|c|}
\hline Study & Year & Tumor type & $\begin{array}{l}\text { No. of } \\
\text { Patients }\end{array}$ & $\begin{array}{l}\text { Male/ } \\
\text { Female }\end{array}$ & $\begin{array}{l}\text { median age } \\
\text { (range) (year) }\end{array}$ & Staining & $\begin{array}{l}\text { TATE: } \\
\text { Present / } \\
\text { absent }\end{array}$ & $\begin{array}{l}\text { Tumor } \\
\text { stage }\end{array}$ & $\begin{array}{l}\text { median follow-up } \\
\text { date (months) }\end{array}$ & Survival & $\begin{array}{l}\text { Quality } \\
\text { Score } \\
\text { (NOS) }\end{array}$ \\
\hline Peurala, E. etal [15] & 2018 & Oral cancer & 99 & $55 / 44$ & 65.3 & $\mathrm{H} \& \mathrm{E}$ & $51 / 47$ & I- III & 40.7 & OS & 8 \\
\hline $\begin{array}{l}\text { Oliveira, D. T. etal } \\
\text { [16] }\end{array}$ & 2012 & Oral cancer & 71 & $55 / 16$ & $59(35,77)$ & $\mathrm{H} \& \mathrm{E}$ & $35 / 36$ & | - || & NR & DFS & 7 \\
\hline $\begin{array}{l}\text { Tostes Oliveira, D. } \\
\text { etal [19] }\end{array}$ & 2009 & Oral cancer & 43 & $27 / 16$ & $55.79(28,83)$ & H\&E & $21 / 22$ & I - IV & $(3,229)$ & OS & 7 \\
\hline $\begin{array}{l}\text { Dorta, R. G. etal } \\
{[17]}\end{array}$ & 2002 & Oral cancer & 125 & $105 / 20$ & $58(30,95)$ & $H \& E$ & $57 / 68$ & II - III & $88.2(0,287.4)$ & $\begin{array}{l}\text { OS, } \\
\text { DFS }\end{array}$ & 7 \\
\hline Dante, P. etal [40] & 2019 & $\begin{array}{l}\text { Tongue } \\
\text { Carcinoma }\end{array}$ & 259 & $223 / 36$ & $53.0 \pm 12.2$ & $\mathrm{H} \& \mathrm{E}$ & NR & I - IV & NR & $\begin{array}{l}\text { OS, } \\
\text { DFS }\end{array}$ & 8 \\
\hline $\begin{array}{l}\text { Alrawi, S. J. etal } \\
\text { [18] }\end{array}$ & 2005 & $\begin{array}{l}\text { Head and neck } \\
\text { carcinoma }\end{array}$ & 87 & NR & $(41,76)$ & H\&E & $13 / 7$ & $\|$ - IV & $36(6,216)$ & $\begin{array}{l}\text { OS, } \\
\text { DFS }\end{array}$ & 7 \\
\hline Ercan, I. etal [20] & 2005 & $\begin{array}{l}\text { Laryngeal } \\
\text { carcinoma }\end{array}$ & 78 & $78 / 0$ & $55.9(35,80)$ & $\mathrm{H} \& \mathrm{E}$ & $25 / 53$ & NR & 41.91 & OS & 7 \\
\hline $\begin{array}{l}\text { Sassler, A. M. etal } \\
\text { [21] }\end{array}$ & 1995 & $\begin{array}{l}\text { Laryngeal } \\
\text { carcinoma }\end{array}$ & 248 & NR & NR & H\&E & $56 / 192$ & III - IV & 48 & $\begin{array}{l}\text { OS, } \\
\text { DFS }\end{array}$ & 6 \\
\hline $\begin{array}{l}\text { Thompson, A. C. } \\
\text { etal [22] }\end{array}$ & 1994 & $\begin{array}{l}\text { Laryngeal } \\
\text { carcinoma }\end{array}$ & 104 & $85 / 19$ & $64.6(39,91)$ & $\mathrm{H} \& \mathrm{E}$ & $31 / 73$ & NR & $\geq 60$ & OS & 6 \\
\hline Fujii, M. etal [23] & 2002 & $\begin{array}{l}\text { Nasopharyngeal } \\
\text { carcinoma }\end{array}$ & 53 & $40 / 13$ & $49.4(15,81)$ & $\mathrm{H} \& \mathrm{E}$ & $26 / 27$ & I - IV & $90.5(35.3,199.9)$ & DFS & 7 \\
\hline $\begin{array}{l}\text { Leighton, S. E. etal } \\
\text { [24] }\end{array}$ & 1996 & $\begin{array}{l}\text { Nasopharyngeal } \\
\text { carcinoma }\end{array}$ & 96 & $68 / 28$ & NR & $\mathrm{H} \& \mathrm{E}$ & $65 / 31$ & NR & 57 & $\begin{array}{l}\text { OS, } \\
\text { DFS }\end{array}$ & 6 \\
\hline $\begin{array}{l}\text { Harbaum, L. etal } \\
\text { [25] }\end{array}$ & 2015 & $\begin{array}{l}\text { Colorectal } \\
\text { cancer }\end{array}$ & 381 & $\begin{array}{l}166 / \\
215\end{array}$ & 68.5 & H\&E & $101 / 280$ & I - IV & $45(1,182)$ & OS & 8 \\
\hline $\begin{array}{l}\text { Fernandez- } \\
\text { Acenero, M. J. etal } \\
{[26]}\end{array}$ & 2000 & $\begin{array}{l}\text { Colorectal } \\
\text { cancer }\end{array}$ & 126 & $70 / 56$ & $67.35(32,87)$ & $\mathrm{H} \& \mathrm{E}$ & 29/97 & $\begin{array}{l}\text { Duke's } \\
\text { A-C }\end{array}$ & $\geq 60$ & $\begin{array}{l}\text { OS, } \\
\text { DFS }\end{array}$ & 8 \\
\hline $\begin{array}{l}\text { Nielsen, H.J. etal } \\
{[27]}\end{array}$ & 1999 & $\begin{array}{l}\text { Colorectal } \\
\text { cancer }\end{array}$ & 584 & $\begin{array}{l}240 / \\
344\end{array}$ & $61(49,75)$ & H\&E & 150/115 & $\begin{array}{l}\text { Duke's } \\
\text { A-D }\end{array}$ & $61(49,75)$ & OS & 7 \\
\hline $\begin{array}{l}\text { Prizment, A. E etal } \\
\text { [28] }\end{array}$ & 2016 & $\begin{array}{l}\text { Colorectal } \\
\text { cancer }\end{array}$ & 441 & $0 / 441$ & $(55,69)$ & $\begin{array}{l}\mathrm{H} \& \mathrm{E}_{i} \\
\mathrm{EPX}\end{array}$ & $197 / 244$ & NR & 60 & OS & 8 \\
\hline Zhang, Y. etal [29] & 2014 & $\begin{array}{l}\text { Esophageal } \\
\text { carcinoma }\end{array}$ & 36 & $25 / 11$ & $59(45,77)$ & $\mathrm{H} \& \mathrm{E}$ & $18 / 18$ & I - IV & $22(2,143)$ & OS & 7 \\
\hline $\begin{array}{l}\text { Ishibashi, S. etal } \\
\text { [30] }\end{array}$ & 2006 & $\begin{array}{l}\text { Esophageal } \\
\text { carcinoma }\end{array}$ & 97 & $82 / 15$ & $62.7 \pm 8.9$ & $\mathrm{H} \& \mathrm{E}$ & $30 / 31$ & NR & $61.7(5.3,165.4)$ & OS & 7 \\
\hline $\begin{array}{l}\text { Hollander, P. etal } \\
\text { [31] }\end{array}$ & 2018 & $\begin{array}{l}\text { Hodgkin's } \\
\text { lymphoma }\end{array}$ & 459 & $\begin{array}{l}242 / \\
217\end{array}$ & $\begin{array}{l}<45: 68 \% \\
\geq 45: 32 \%\end{array}$ & $\mathrm{H} \& \mathrm{E}$ & $N R$ & I - IV & 154.8 & OS & 8 \\
\hline $\begin{array}{l}\text { Kereszres, K. etal } \\
\text { [32] }\end{array}$ & 2007 & $\begin{array}{l}\text { Hodgkin's } \\
\text { lymphoma }\end{array}$ & 104 & $54 / 50$ & $33(12,72)$ & $\mathrm{H} \& \mathrm{E}$ & $64 / 40$ & I - IV & $110(24,214)$ & $\begin{array}{l}\text { OS, } \\
\text { DFS }\end{array}$ & 7 \\
\hline $\begin{array}{l}\text { von Wasielewski, R. } \\
\text { etal [33] }\end{array}$ & 2000 & $\begin{array}{l}\text { Hodgkin's } \\
\text { lymphoma }\end{array}$ & 1511 & $\begin{array}{l}745 / \\
766\end{array}$ & $(15,75)$ & $\mathrm{H} \& \mathrm{E}$ & $510 / 823$ & I - IV & 120 & OS & 8 \\
\hline Enblad, G.etal [34] & 1993 & $\begin{array}{l}\text { Hodgkin's } \\
\text { lymphoma }\end{array}$ & 140 & NR & $45(11,94)$ & $\mathrm{H} \& \mathrm{E}$ & $26 / 114$ & I - IV & $48(20,85)$ & DFS & 6 \\
\hline $\begin{array}{l}\text { van Driel, W.J. etal } \\
\text { [35] }\end{array}$ & 1996 & Cervical cancer & 83 & $0 / 83$ & 42.1 & $\mathrm{H} \& \mathrm{E}$ & NR & I- $\| A$ & $44.6(5,108)$ & $\begin{array}{l}\text { OS, } \\
\text { DFS }\end{array}$ & 7 \\
\hline $\begin{array}{l}\text { Bethwaite, P. B. etal } \\
\text { [36] }\end{array}$ & 1993 & Cervical cancer & 67 & $0 / 67$ & $43.7(25,76)$ & $\mathrm{H} \& \mathrm{E}$ & 28/39 & $\mathrm{IB}$ & $62.4(1,93)$ & OS & 7 \\
\hline Flamm, J. etal [37] & 1992 & Bladder cancer & 428 & $\begin{array}{l}289 / \\
139\end{array}$ & $70.2(29,91)$ & $\mathrm{H} \& \mathrm{E}$ & $99 / 329$ & $N R$ & 84 & OS & 7 \\
\hline Iwasaki, K. etal [38] & 1986 & Gastric cancer & 647 & $\begin{array}{l}364 / \\
283\end{array}$ & $(22,84)$ & $\mathrm{H} \& \mathrm{E}$ & $157 / 490$ & I - IV & $(8,92)$ & OS & 7 \\
\hline Ono, Y. etal [39] & 2002 & Penile cancer & 17 & $17 / 0$ & $68(36,84)$ & $H \& E$ & $9 / 8$ & I - IV & NR & OS & 6 \\
\hline
\end{tabular}


infections etc. [5] These cells secrete massive proteins and cytokines upon activation and are involved in a variety of other functions including inducing tissue remodeling and promoting antigen presentation [6]. In the last decade, activated eosinophils have been deemed to affect carcinogenesis and tumor progression via various mechanisms including modulating innate and adaptive immune responses in TME [7]. Eosinophils infiltrating into tumor is also called tumor-associated tissue eosinophilia (TATE) [8]. Recent researches have investigated the TATE in tumor progression and survival, but their results were inconsistent even contradictory [9]. Hence, it needs further evaluation. In addition, the potential of TATE as prognostic biomarker and therapeutic strategy is also required to be investigated.

Herein, we carried out this meta-analysis to expound the relation between TATE and clinical outcomes including overall survival (OS) and disease-free survival (DFS) in patients with cancer.

\section{Methods}

\section{Search strategy}

This meta-analysis was guided by the PRISMA (Preferred Reporting Items for Systematic Reviews and Meta-Analysis) Statement issued in 2009 (Checklist S1). PubMed, Embase and EBSCO were searched for researches from 1980 to May 15th 2019. The keywords applied for search were: (eosinophil [Title/Abstract] OR eosinophilia [Title/Abstract]) AND (neoplasms [Title/ Abstract] OR tumor [Title/Abstract] OR cancer [Title/ Abstract] OR carcinoma [Title/Abstract]).

\section{Inclusion and exclusion criteria}

Researches included in this meta-analysis should meet the following inclusion criteria: (1) been published as original articles; (2) investigated human subjects; (3) examined eosinophils in primary tumor tissues; (4) reported hazard ratios (HRs) with 95\% confidence interval (CI), or Kaplan - Meier curves of eosinophil infiltration with clinical outcomes.

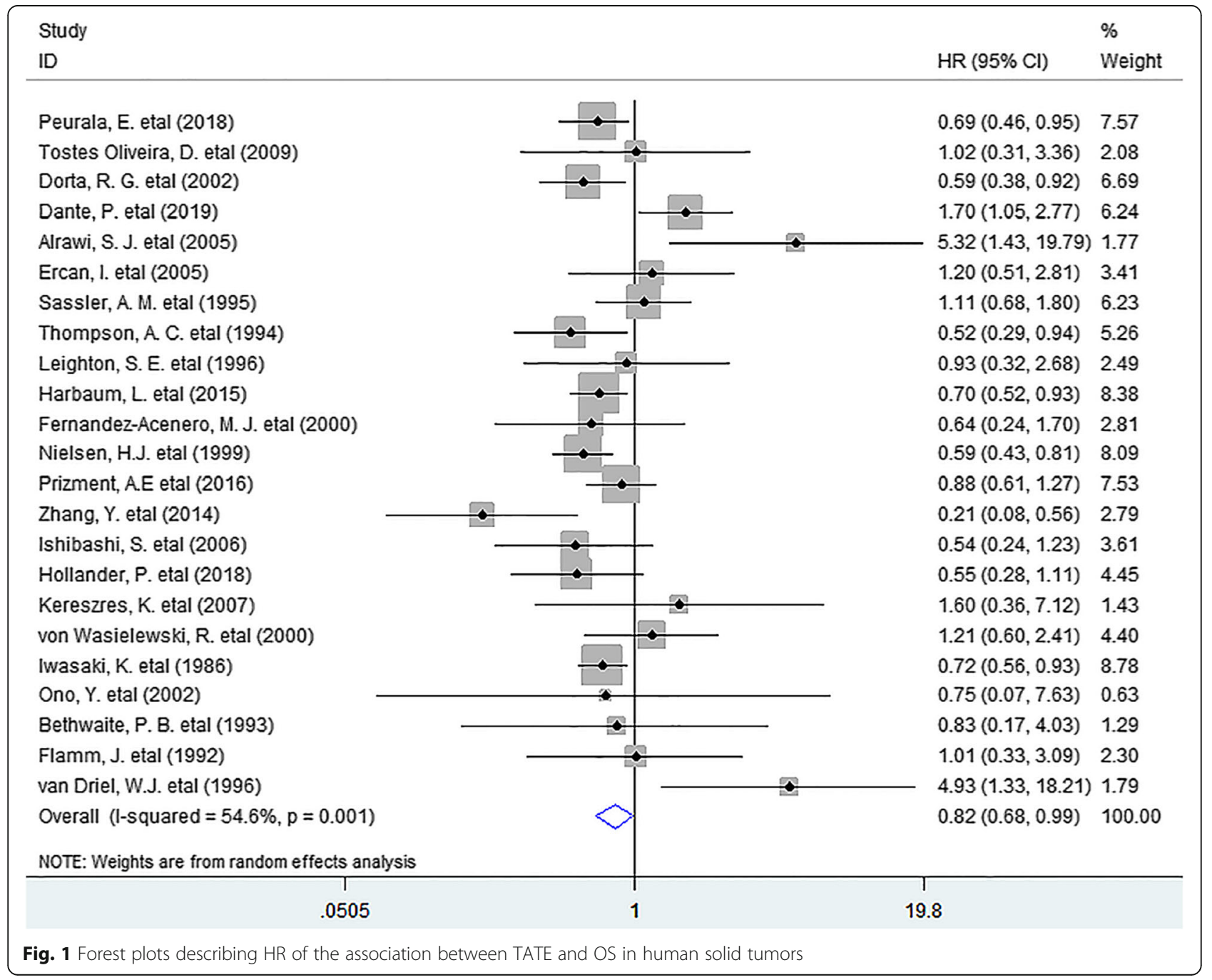


The exclusion criteria were as follows: researches (1) were not published as research articles or full texts including commentaries, case reports, letters to the editors and meeting abstracts; (2) didn't offer ample data to obtain HRs; (3) investigated eosinophils in metastases or not in tumor tissues.

\section{Endpoints}

In this study, OS and DFS were regarded as the primary and second endpoint respectively.

\section{Data extraction}

GM.H. and SM.W. reviewed and recorded data including number of patients, method to quantify eosinophils, cutoff value to determine TATE and time of follow-up etc. independently. OS, DFS and clinicopathological features such as tumor, node, metastasis (TNM) stage and lymphatic invasion were extracted from the text, tables, or Kaplan - Meier curves.

\section{Quality assessment}

Two authors independently assessed the quality of included cohort researches with Newcastle-Ottawa Scale (NOS), [10] and achieved consensus for each item under the help of third or more authors. Research scored 6 or above was regarded as high quality.

\section{Statistical analysis}

We combined extracted data using STATA 12.0 analysis software, and estimated statistical heterogeneity with the

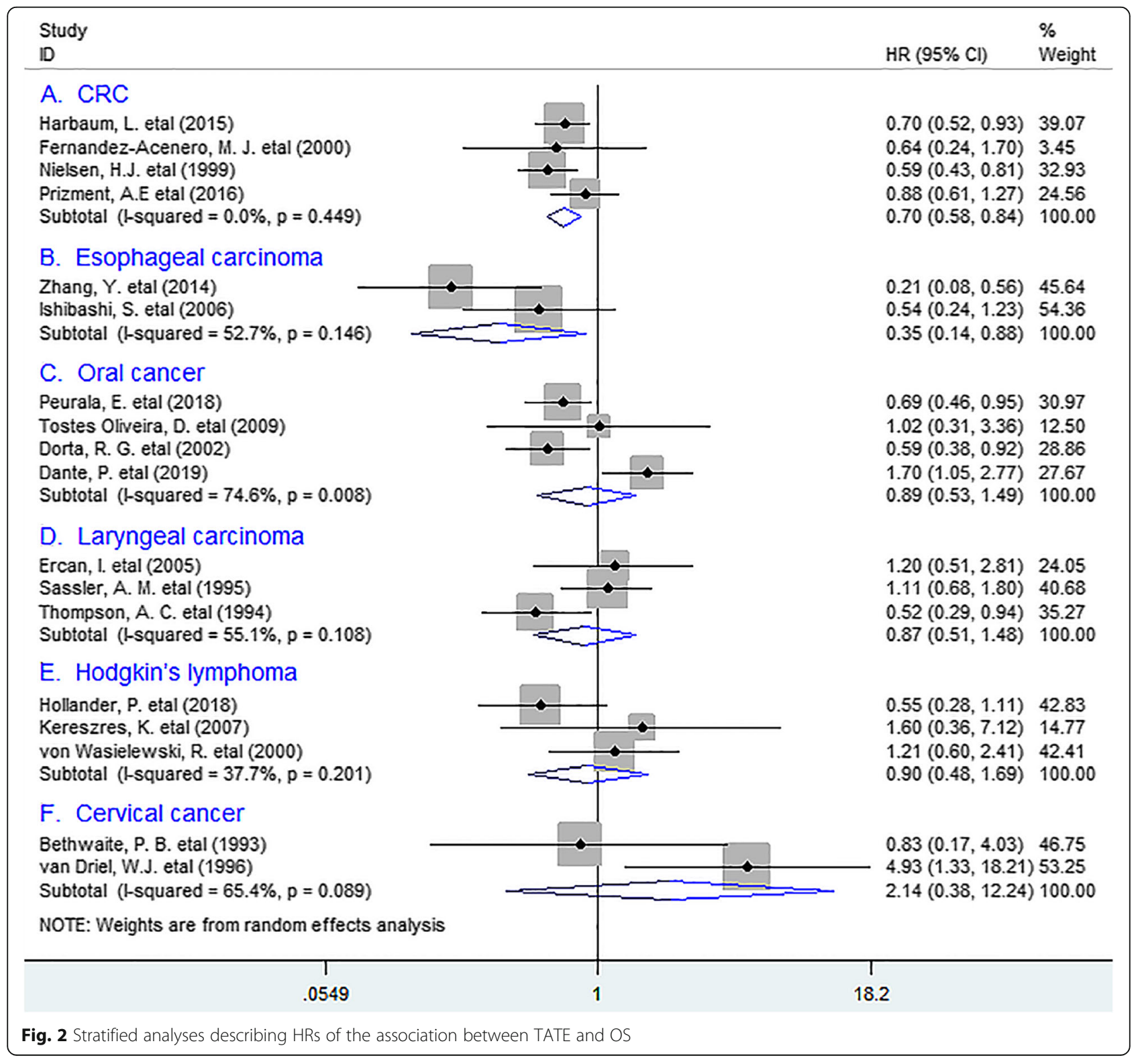


chi-squared based Q-test or $I^{2}$ (25\% was considered lowlevel heterogeneity, 25-50\% moderate-level heterogeneity, and 50\% high-level heterogeneity) [11]. Data were pooled based on the random-effect model in the presence of heterogeneity, [12] otherwise, the fixed-effect model was applied [13]. In addition, stratified analyses were conducted based on tumor types; sensitivity analysis, Begg's funnel plot and Egger's test [14] were employed to explore the impact of each research on the overall result and potential publication bias respectively. All $P$ values were two-sided and below 0.05 was treated as statistical significance.

\section{Results}

\section{Search results and description of studies}

Flow chart diagram of research selection was displayed in Fig. S1. Twenty six researches with 6384 patients were ultimately included in this meta-analysis [15-40]. And all the researches were scored 6 or above after careful evaluation with the NewcastleOttawa Scale (NOS); Characteristics of those researches being in the light of the inclusion criteria and suitable for data incorporation were exhibited in Table 1 and Table S1.

\section{Meta-analyses}

Overall survival (OS)

In this meta-analysis, we discovered that the presence of TATE was notably associated with improved OS (HR = $0.82,95 \%$ CI 0.68 to $0.99, P=0.041$ ) in patients with solid tumor. (Fig. 1).

In stratified analyses according to tumor types, the combined results manifested that TATE was markedly associated with better OS in colorectal cancer (CRC) (HR $=0.70,95 \%$ CI 0.58 to $0.84, P=0.000$ ), with no heterogeneity detected $\left(I^{2}=0 \%, P=0.449\right)$. Similar data was obtained between TATE and OS in esophageal carcinoma (EC) $(\mathrm{HR}=0.35,95 \% \mathrm{CI} 0.14$ to 0.88 , $P=0.026)$; Whereas no distinct relation existed between eosinophil infiltration and OS in oral cancer (OC) $(\mathrm{HR}=0.89,95 \% \mathrm{CI} 0.53$ to $1.49, P=0.657)$, laryngeal carcinoma $(\mathrm{HR}=0.87,95 \% \mathrm{CI} 0.51$ to 1.48 , $P=0.599)$, Hodgkin's lymphoma $(\mathrm{HR}=0.90,95 \% \mathrm{CI}$ 0.48 to $1.69, P=0.741)$ or cervical cancer $(\mathrm{HR}=2.14$, $95 \%$ CI 0.38 to $12.24, P=0.391$ ). (Fig. 2).

\section{Disease-free survival (DFS)}

As for DFS, the meta-analysis indicated that no noticeable association existed between eosinophil infiltration and DFS (HR $=1.13,95 \%$ CI 0.72 to $1.77, P=0.598)$ in solid

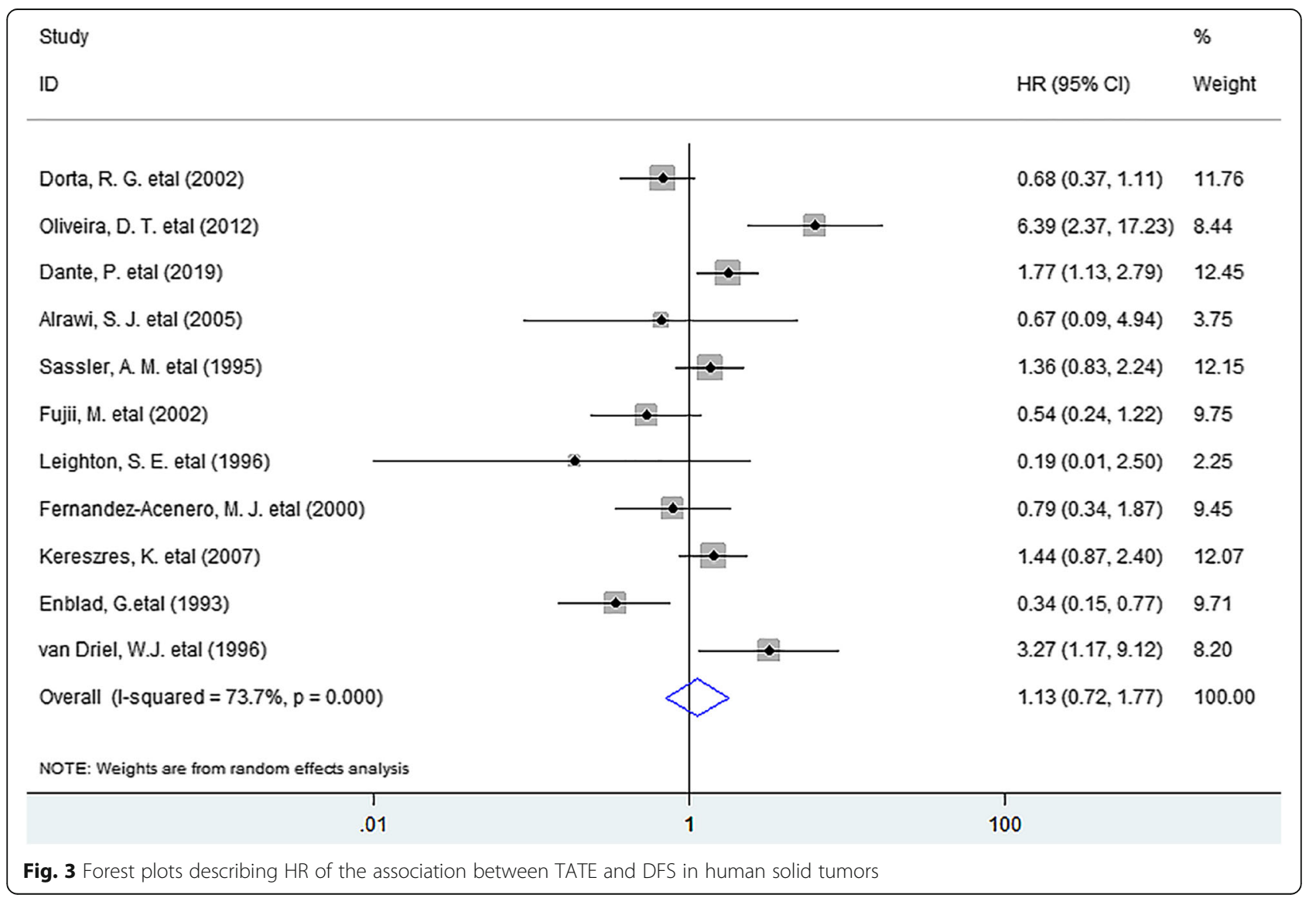


tumors. (Fig. 3) In the stratified analyses, the incorporated results revealed that TATE was not significantly associated with improved DFS in oral cancer (HR $=1.83,95 \%$ CI 0.65 to $5.15, P=0.253)$, nasopharyngeal carcinoma ( $\mathrm{HR}=0,50$, 95\% CI 0.23 to $1.08, P=0.079$ ) or Hodgkin's lymphoma $(\mathrm{HR}=0.73,95 \% \mathrm{CI} 0.18$ to $2.98, P=0.657)$. (Fig. 4 ).

\section{Clinicopathological features}

We next tested the relation between TATE and clinicopathological features, and found that TATE was remarkably inversely correlated with lymph node metastasis ( $\mathrm{OR}=0.59,95 \%$ CI 0.40 to $0.87, P=0.007$ ), TNM stage $(\mathrm{OR}=1.70,95 \%$ CI 1.12 to $2.58, P=0.013)$ and lymphatic invasion ( $\mathrm{OR}=0.58,95 \% \mathrm{CI} 0.36$ to $0.91, P=0.018)$, but not with vascular invasion $(\mathrm{OR}=0.79,95 \% \mathrm{CI} 0.50$ to $1.25, P=0.308$ ) of patients. (Fig. 5).

\section{Sensitivity analysis}

Sensitivity analysis demonstrated that each included research had no impact on the overall result for OS or DFS. (Fig. S2).

\section{Publication bias}

No publication bias existed between TATE and OS $(P=0.152)$ or DFS $(P=0.876)$ in patients by Funnel plot (Fig. S3) and Egger's test.

\section{Discussion}

Eosinophilia is commonly associated with allergies, helminth infections and several inflammatory states. Recently, it has also been noted in human solid tumors. The present meta-analysis revealed that TATE had a positive effect in improving survival in human solid tumors, especially in CRC and EC. Moreover, It significantly inversely correlated with lymph node metastasis etc. of tumor. Hence, these data offered important evidence in uncovering the positive prognostic role of TATE in human solid tumors.

The close relation between TATE and better clinical outcome identified in this study possibly attribute to the following reasons: eosinophils in the TME can express same receptors and mediators such as granzyme A etc. as cytotoxic $\mathrm{T}$ lymphocytes (CTLs) and be directly involved in anti-tumor response, [41] and they can also secret several chemokines including CCL5, CXCL9 to promote anti-

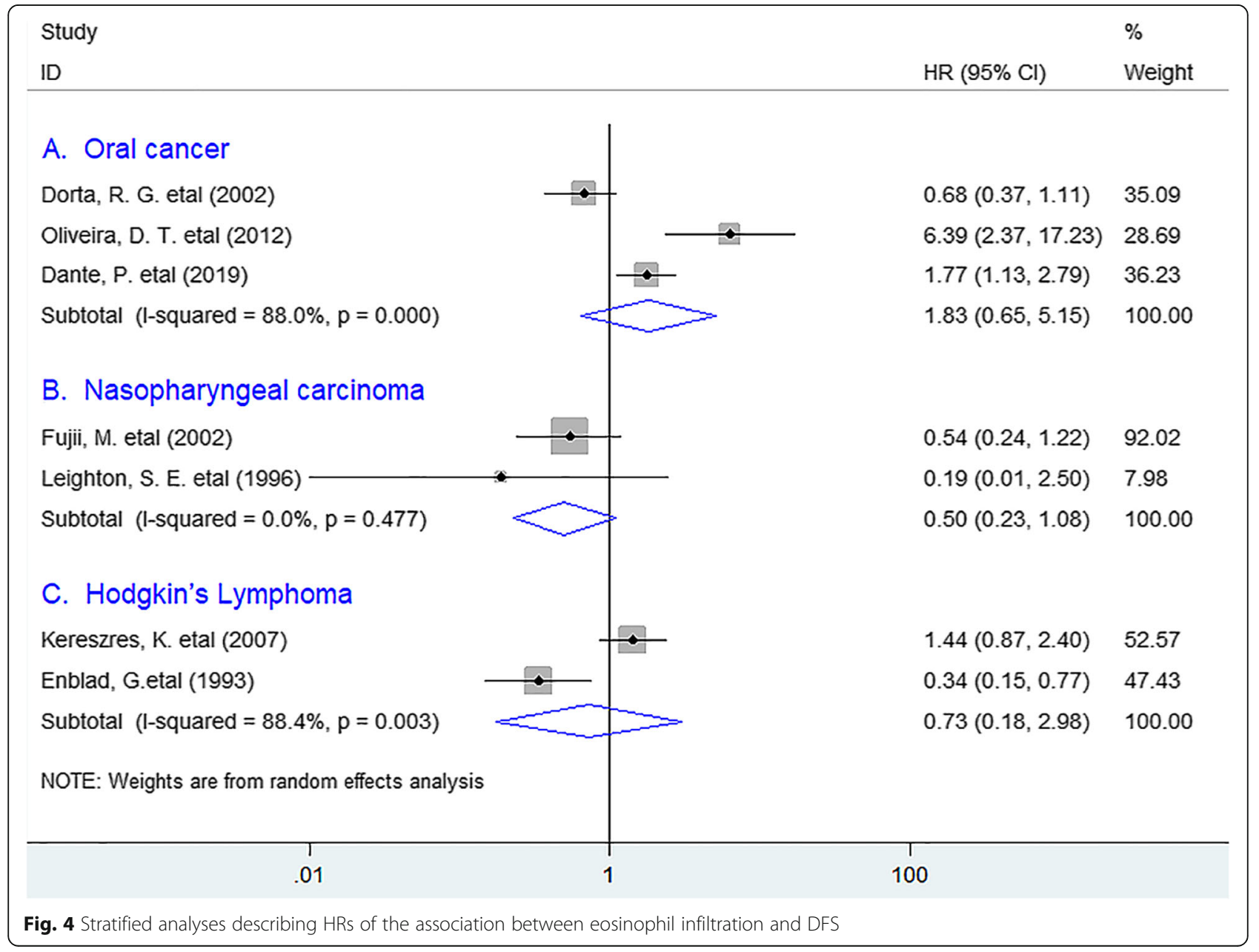




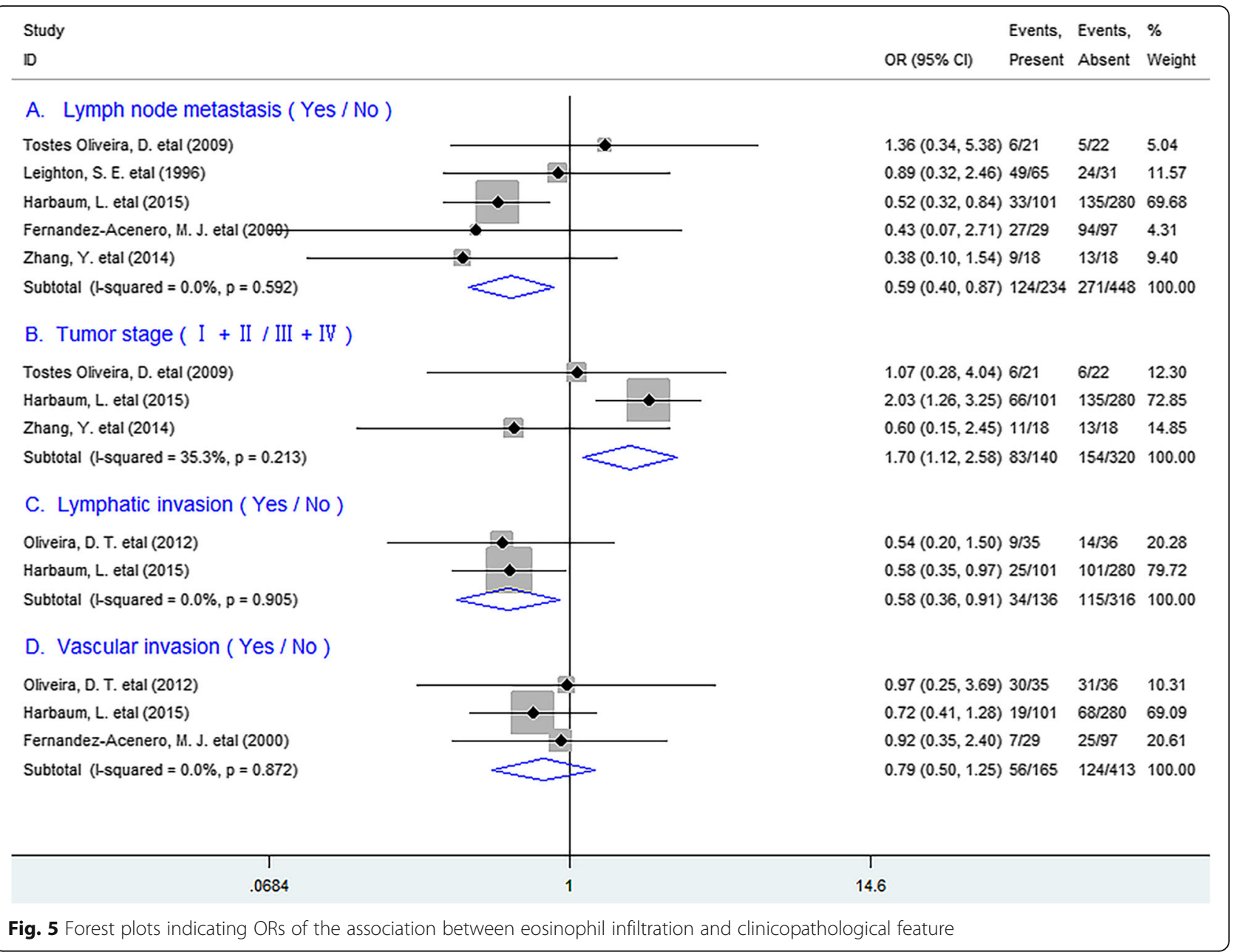

tumor immunity through attracting $\mathrm{CD}^{+} \mathrm{T}$ cells to the tumor site [42]. In addition, eosinophils are capable of regulating immunity, for instance, they can release major basic protein (MBP), a highly cationic protein to stimulate maturation of dendritic cells by increasing cell surface activation markers including MHC-II, CD80 and CD86, [43] which has the potential to overcome immune tolerance and induce anti-tumor immunity with the powerful antigenpresentation ability [44]. Furthermore, they can induce cell death of various cell lines such as colo-205 cell line with some selectivity in their tumoricidal properties, which are dependent on the CD11a/CD18-mediated stable contacts with target cells [45]. Hence, it is rational to conclude that TATE is capable of regulating tissue homeostasis of the TME and inhibiting tumor growth and metastasis thereby improving survival. However, in other tumor types, TATE as a prognostic marker for survival has been a controversial issue. This may be because of differences in methods of counting TATE as well as heterogeneity of material.

Previous studies have demonstrated that cytokines such as IL-2, IL-4 could recruit eosinophils and lead to eosinophilia and enhanced eosinophil activation, thereby exert potent anti-tumor immune responses [41, 46]. Thus, based on our present result that TATE improving survival in human solid tumors identified in this study and the function of IL- 2 and IL- 4 stated above, we harbor the idea that clinical application of biological response modifiers (BRM) such as carrier-assisted recombined human IL-2 /or IL-4 may have the potential to treat human solid tumors.

Quite a few limitations should be noted from this study. First, morphometric analyses for TATE adopted in included researches were not exactly consistent. In addition, researches with negative results might not be published, which might result in potential publication bias.

\section{Conclusions}

TATE promotes survival in solid tumors especially in CRC and EC, suggesting that it is a valuable prognostic biomarker and clinical application of biological response modifiers or agonists promoting TATE may be a novel therapeutic strategy for patients. 


\section{Supplementary information}

Supplementary information accompanies this paper at https://doi.org/10. 1186/s12885-020-06966-3.

Additional file 1: Figure S1. Flow chart diagram of study selection. Figure S2. Plots describing the influence of individual studies on the overall HRs for OS (A) and DFS (B) in human cancers. Figure S3. Funnel plots displayed the potential publication bias between TATE and OS (A) or DFS (B) in patients. Table S1. Characteristics of the included studies for OR analysis of clinicopathological features.

\section{Abbreviations}

TATE: Tumor-associated tissue eosinophilia; OS: Overall survival; DFS: Diseasefree survival; HR: Hazard ratio; OR: Odds ratio; Cl: Confidence interval; TNM: Tumor, node, metastasis; OC: Oral cancer; CRC: Colorectal cancer; EC: Esophageal carcinoma; NR: Not reported; TME: Tumor microenvironment; BRM: Biological response modifier

\section{Acknowledgements}

Not applicable.

\section{Authors' contributions}

GM.H. conceived of the study, participated in its design, extracted data, performed the statistical analysis and drafted the manuscript. SM.W. participated in data extraction; KF.Z., F. X. and LM.H. participated in statistical analysis and manuscript revision. W.C. and P.C. participated in its design and manuscript revision. All authors read and approved the final manuscript.

\section{Funding}

This work was funded by the National Natural Science Foundation of China (Grant No. 81702803, GMH) and was also partly supported by Shaoxing Science and Technology Plan Project (2018C30055, LMH; 2018C30075, KFZ; $2017 B 70036, F X)$. We used the funding to perform data collection, analysis and interpretation.

\section{Availability of data and materials}

The datasets supporting the conclusions of this article are included within the article.

\section{Ethics approval and consent to participate}

The ethical approval was unnecessary because this study based on summary and analysis of the results of previous studies.

\section{Consent for publication}

Not applicable.

\section{Competing interests}

The authors have declared that no competing interests exist.

\section{Author details}

'Department of General Surgery (Breast and Thyroid Surgery), Shaoxing People's Hospital (Shaoxing Hospital, Zhejiang University School of Medicine), Zhejiang 312000, China. '2Department of Nephrology, Shaoxing People's Hospital (Shaoxing Hospital, Zhejiang University School of Medicine), Zhejiang 312000, China. ${ }^{3}$ Department of Gynecology, Second Affiliated Hospital, Zhejiang University School of Medicine, Zhejiang University, Hangzhou 310009, China.

Received: 26 May 2019 Accepted: 14 May 2020

Published online: 20 May 2020

\section{References}

1. Motz GT, Coukos G. The parallel lives of angiogenesis and immunosuppression: cancer and other tales. Nat Rev Immunol. 2011;11(10): 702-11

2. Gajewski TF, Schreiber H, Fu YX. Innate and adaptive immune cells in the tumor microenvironment. Nat Immunol. 2013:14(10):1014-22.

3. Hu G, Wang S, Cheng P. Tumor-infiltrating tryptase(+) mast cells predict unfavorable clinical outcome in solid tumors. Int J Cancer. 2018;142(4): 813-21.
4. Hu G, Wang S. Tumor-infiltrating CD45RO+ Memory T Lymphocytes Predict Favorable Clinical Outcome in Solid Tumors. Sci Rep. 2017:7(1).

5. Hogan SP, Rosenberg HF, Moqbel R, Phipps S, Foster PS, Lacy P, Kay AB, Rothenberg ME. Eosinophils: biological properties and role in health and disease. Clin Exp Allergy. 2008;38(5):709-50.

6. Akuthota P, Wang HB, Spencer LA, Weller PF. Immunoregulatory roles of eosinophils: a new look at a familiar cell. Clin Exp Allergy. 2008;38(8): 1254-63.

7. Kita H. Eosinophils: multifaceted biological properties and roles in health and disease. Immunol Rev. 2011;242(1):161-77.

8. Jain M, Kasetty S, Sudheendra US, Tijare M, Khan S, Desai A. Assessment of tissue eosinophilia as a prognosticator in oral epithelial dysplasia and oral squamous cell carcinoma-an image analysis study. Pathol Res Int. 2014;2014: 507512.

9. Marichal T, Tsai M, Galli SJ. Mast cells: potential positive and negative roles in tumor biology. Cancer Immunol Res. 2013;1(5):269-79.

10. Stang A. Critical evaluation of the Newcastle-Ottawa scale for the assessment of the quality of nonrandomized studies in meta-analyses. Eur J Epidemiol. 2010;25(9):603-5.

11. Higgins JP, Thompson SG, Deeks JJ, Altman DG. Measuring inconsistency in meta-analyses. BMJ. 2003:327(7414):557-60.

12. Kuritz SJ, Landis JR, Koch GG. A general overview of mantel-Haenszel methods: applications and recent developments. Annu Rev Public Health. 1988;9:123-60.

13. DerSimonian R, Kacker R. Random-effects model for meta-analysis of clinical trials: an update. Contemp Clin Trials. 2007;28(2):105-14.

14. Egger M, Davey Smith G, Schneider M, Minder C. Bias in meta-analysis detected by a simple, graphical test. BMJ. 1997;315(7109):629-34.

15. Peurala E, Tuominen M, Loyttyniemi E, Syrjanen S, Rautava J. Eosinophilia is a favorable prognostic marker for oral cavity and lip squamous cell carcinoma. APMIS. 2018;126(3):201-7.

16. Oliveira DT, Biassi TP, Faustino SE, Carvalho AL, Landman G, Kowalski LP. Eosinophils may predict occult lymph node metastasis in early oral cancer. Clin Oral Investig. 2012;16(6):1523-8.

17. Dorta RG, Landman G, Kowalski LP, Lauris JR, Latorre MR, Oliveira DT. Tumour-associated tissue eosinophilia as a prognostic factor in oral squamous cell carcinomas. Histopathology. 2002;41(2):152-7.

18. Alrawi SJ, Tan D, Stoler DL, Dayton M, Anderson GR, Mojica P, Douglas W Hicks W Jr, Rigual N, Loree T. Tissue eosinophilic infiltration: a useful marker for assessing stromal invasion, survival and locoregional recurrence in head and neck squamous neoplasia. Cancer J. 2005;11(3):217-25.

19. Tostes Oliveira D, Tjioe KC, Assao A, Sita Faustino SE, Lopes Carvalho A, Landman G, Kowalski LP. Tissue eosinophilia and its association with tumoral invasion of oral cancer. Int J Surg Pathol. 2009;17(3):244-9.

20. Ercan I, Cakir B, Basak T, Ozdemir T, Sayin I, Turgut S. Prognostic significance of stromal eosinophilic infiltration in cancer of the larynx. Otolaryngol Head Neck Surg. 2005;132(6):869-73.

21. Sassler AM, McClatchey KD, Wolf GT, Fisher SG. Eosinophilic infiltration in advanced laryngeal squamous cell carcinoma. Veterans administration laryngeal cooperative study group. Laryngoscope. 1995;105(4 Pt 1):413-6.

22. Thompson AC, Bradley PJ, Griffin NR. Tumor-associated tissue eosinophilia and long-term prognosis for carcinoma of the larynx. Am J Surg. 1994; 168(5):469-71.

23. Fujii M, Yamashita T, Ishiguro R, Tashiro M, Kameyama K. Significance of epidermal growth factor receptor and tumor associated tissue eosinophilia in the prognosis of patients with nasopharyngeal carcinoma. Auris Nasus Larynx. 2002;29(2):175-81.

24. Leighton SE, Teo JG, Leung SF, Cheung AY, Lee JC, van Hasselt CA. Prevalence and prognostic significance of tumor-associated tissue eosinophilia in nasopharyngeal carcinoma. Cancer. 1996;77(3):436-40.

25. Harbaum L, Pollheimer MJ, Kornprat P, Lindtner RA, Bokemeyer C, Langner C. Peritumoral eosinophils predict recurrence in colorectal cancer. Mod Pathol. 2015;28(3):403-13.

26. Fernandez-Acenero MJ, Galindo-Gallego M, Sanz J, Aljama A. Prognostic influence of tumor-associated eosinophilic infiltrate in colorectal carcinoma. Cancer. 2000;88(7):1544-8.

27. Nielsen HJ, Hansen U, Christensen IJ, Reimert CM, Brunner N, Moesgaard F Independent prognostic value of eosinophil and mast cell infiltration in colorectal cancer tissue. J Pathol. 1999;189(4):487-95.

28. Prizment $A E$, Vierkant RA, Smyrk TC, Tillmans LS, Lee JJ, Sriramarao P, Nelson $\mathrm{HH}$, Lynch CF, Thibodeau SN, Church TR, Cerhan JR, Anderson KE, Limburg 
PJ. Tumor eosinophil infiltration and improved survival of colorectal cancer patients: lowa Women's health study. Mod Pathol. 2016;29(5):516-27.

29. Zhang Y, Ren H, Wang L, Ning Z, Zhuang Y, Gan J, Chen S, Zhou D, Zhu H, Tan D, Zhang H. Clinical impact of tumor-infiltrating inflammatory cells in primary small cell esophageal carcinoma. Int J Mol Sci. 2014;15(6):9718-34.

30. Ishibashi S, Ohashi Y, Suzuki T, Miyazaki S, Moriya T, Satomi S, Sasano H. Tumor-associated tissue eosinophilia in human esophageal squamous cell carcinoma. Anticancer Res. 2006;26(2B):1419-24.

31. Hollander P, Rostgaard K, Smedby KE, Molin D, Loskog A, de Nully BP, Enblad G, Amini RM, Hjalgrim H, Glimelius I. An anergic immune signature in the tumor microenvironment of classical Hodgkin lymphoma is associated with inferior outcome. Eur J Haematol. 2018;100(1):88-97.

32. Keresztes K, Szollosi Z, Simon Z, Tarkanyi I, Nemes Z, Illes A. Retrospective analysis of the prognostic role of tissue eosinophil and mast cells in Hodgkin's lymphoma. Pathol Oncol Res. 2007;13(3):237-42.

33. von Wasielewski R, Seth S, Franklin J, Fischer R, Hubner K, Hansmann ML, Diehl V, Georgii A. Tissue eosinophilia correlates strongly with poor prognosis in nodular sclerosing Hodgkin's disease, allowing for known prognostic factors. Blood. 2000;95(4):1207-13.

34. Enblad G, Sundstrom C, Glimelius B. Infiltration of eosinophils in Hodgkin's disease involved lymph nodes predicts prognosis. Hematol Oncol. 1993; 11(4):187-93.

35. van Driel WJ, Hogendoorn PC, Jansen FW, Zwinderman AH, Trimbos JB, Fleuren GJ. Tumor-associated eosinophilic infiltrate of cervical cancer is indicative for a less effective immune response. Hum Pathol. 1996;27(9):904-11.

36. Bethwaite PB, Holloway $L J$, Yeong ML, Thornton A. Effect of tumour associated tissue eosinophilia on survival of women with stage IB carcinoma of the uterine cervix. J Clin Pathol. 1993;46(11):1016-20.

37. Flamm J. Tumor-associated tissue inflammatory reaction and eosinophilia in primary superficial bladder cancer. Urology. 1992;40(2):180-5.

38. Iwasaki K, Torisu M, Fujimura T. Malignant tumor and eosinophils. I. Prognostic significance in gastric cancer. Cancer. 1986;58(6):1321-7.

39. Ono Y, Ozawa M, Tamura Y, Suzuki T, Suzuki K, Kurokawa K, Fukabori Y, Yamanaka H. Tumor-associated tissue eosinophilia of penile cancer. Int J Urol. 2002;9(2):82-7.

40. Paz D, Chang KP, Kao HK, Lao WWK, Huang YC, Chang YL, Huang Y. Clinical implications of tumor-associated tissue eosinophilia in tongue squamous cell carcinoma. Laryngoscope. 2018;129(5):1123-9.

41. Gatault S, Legrand F, Delbeke M, Loiseau S, Capron M. Involvement of eosinophils in the anti-tumor response. Cancer Immunol Immunother. 2012; 61(9):1527-34

42. Carretero R, Sektioglu IM, Garbi N, Salgado OC, Beckhove P, Hammerling GJ. Eosinophils orchestrate cancer rejection by normalizing tumor vessels and enhancing infiltration of CD8(+) T cells. Nat Immunol. 2015;16(6):609-17.

43. Lotfi R, Lotze MT. Eosinophils induce DC maturation, regulating immunity. J Leukoc Biol. 2008;83(3):456-60

44. Sheng KC, Pietersz GA, Wright MD, Apostolopoulos V. Dendritic cells: activation and maturation--applications for cancer immunotherapy. Curr Med Chem. 2005;12(15):1783-800.

45. Legrand F, Driss V, Delbeke M, Loiseau S, Hermann E, Dombrowicz D, Capron M. Human eosinophils exert TNF-alpha and granzyme A-mediated tumoricidal activity toward colon carcinoma cells. J Immunol. 2010;185(12):7443-51.

46. Sosman JA, Bartemes K, Offord KP, Kita H, Fisher SG, Kefer C, Ellis TA, Fisher Rl, Higgins TJ, Gleich GJ. Evidence for eosinophil activation in cancer patients receiving recombinant interleukin-4: effects of interleukin-4 alone and following interleukin-2 administration. Clin Cancer Res. 1995; 1(8):805-12.

\section{Publisher's Note}

Springer Nature remains neutral with regard to jurisdictional claims in published maps and institutional affiliations.

\section{Ready to submit your research? Choose BMC and benefit from}

- fast, convenient online submission

- thorough peer review by experienced researchers in your field

- rapid publication on acceptance

- support for research data, including large and complex data types

- gold Open Access which fosters wider collaboration and increased citations

- maximum visibility for your research: over $100 \mathrm{M}$ website views per year

At BMC, research is always in progress.

Learn more biomedcentral.com/submissions 